\title{
Determinants of enterprise risk management disclosures: Evidence from insurance industry
}

\author{
Dirvi Surya Abbas ${ }^{a^{*}}$, Tubagus Ismail ${ }^{\mathrm{b}}$, Muhamad Taqi ${ }^{\mathrm{b}}$ and Helmi Yazid
}

a Phd Scholar, Sultan Ageng Tirtayasa of University, Indonesia

${ }^{b}$ Sultan Ageng Tirtayasa of University, Indonesia

\section{H R O N I C L E \\ A B S T R A C T}

\section{Article history:}

Received: November 30, 2020

Received in revised format:

April 32021

Accepted: April 4, 2021

Available online:

April 6, 2021

Keywords:

Disclosure of Enterprise Risk

Management

Board of Commissioners Size

Ownership Concentration

Risk Management Committee

Company Size

Leverage

\begin{abstract}
The aim of this study is to determine if there is a relationship between the number of commissioners on the committee, ownership concentration, the Risk Management Committee, business size, and leverage on enterprise risk management. Take, for example, insurance companies listed on the Indonesia Stock Exchange. Purposeful sampling was used in the sampling process. Supplementary data was obtained from the website of the Indonesia Stock Exchange. Panel data regression analysis was used as the research method. Although business size had an effect on enterprise risk management transparency, board size, stake concentration, the risk management committee, and leverage had little effect. By integrating the variables Board of Commissioners Size and Ownership Concentration, as well as employing dynamic equation modeling to examine the above relationships, which have been overlooked in previous analyses, and analyzing more recent evidence from a developed world perspective, this study contributes to the management accounting literature and organization theory. The findings would be useful to Indonesian practitioners, especially those in management positions in insurance companies and financial institutions.
\end{abstract}

C) 2021 by the authors; licensee Growing Science, Canada

\section{Introduction}

Without a doubt, small and medium-sized companies (SMEs) are critical components of global economic growth and prosperity (Alahmari, 2020; Ayyagari, Beck, \& Demirguc-Kunt, 2007; Burgstaller, 2013). Financing and capital structure decisions are one area where the special features of small and medium-sized enterprises (SMEs) (FF) and their competitive landscape must be understood when putting conventional economic models to the test (Burgstaller, 2013). Previous economic shocks exposed business complexities and volatility, igniting a vigorous discussion over the importance of applying corporate risk management (ERM) (Bromiley, McShane, Nair, \& Rustambekov, 2015). The annual report on risk management transparency is one of the factors that investors weigh when making decisions. The significance of information transparency in the annual report because the annual report includes disclosures and results of business growth. According to the solution to help rebuild consumer trust and monitor the actions of management levels in order to deal with corporate fraud, business risk management transparency is needed. Annual reviews or annual reports provide information on corporate risk control disclosures. The willingness of a SME owner/top SME boss to make rational decisions is vital to maintaining the financial prosperity and long-term survival of SMEs in today's industry (Cepel, Stasiukynas, Kotaskova, \& Dvorsky, 2018). In the absence of a seamless digitalization mechanism, business decisions are made with complexity and risk. Small and medium-sized companies (SMEs) are becoming more mindful of the value of risk management and regulation. (Dvorsky, 2020).

* Corresponding author.

E-mail address: abbas.dirvi@gmail.com (D. S. Abbas) 
Many commissioners on the board of directors make oversight of enforcing management risk disclosures in the organization inefficient. The existence of a board of commissioners can have an effect on the amount of information disclosed about corporate risk management. The composition of the board of commissioners relates to the number of members who come from both within and outside the corporation and are tasked with conducting general and unique oversight and providing recommendations to the board of directors. The role of the board of commissioners is hoped to increase risk transparency by management through the financial statement oversight process. The board of commissioners in risk management can prevent any indication of confidential information by exercising adequate oversight. The structure of a company's board of commissioners, on the other hand, is not the most critical determinant of management oversight effectiveness. Manurung and Kusumah (2016) and Sulistyaningsih and Gunawan (2018) were the researchers who found that the structure of the board of commissioners has an effect on the disclosure of Enterprise Risk Management. In addition to the study's results (Dzakawali, Nazar, \& Yudowati, 2017), the scale of the board of commissioners has no bearing on business risk management disclosure. The more concentrated ownership, the more it will affect the decision making for enterprise risk management disclosure. Ownership concentration is also thought to influence Enterprise Risk Management's disclosure in this study because ownership concentration will increase management control. After all, it has the power to exercise tighter supervision and control. The creation of the Risk Management Committee has resulted in a rise in transparency of business management risk, which has an effect on the amount of reported company records, which becomes a consideration for customers to invest in the company and can increase the company's costs. The company's size causes more disclosures made by the company; it will have an impact on the amount of information that must be published and the amount of costs that the company will incur. The higher the level of leverage, the more risk there is difficulty paying obligations and interest, causing the company to tend to disclose less risk management. The uncertainty of prior studies' study findings is most likely attributed to other component variables affecting Enterprise Risk Management transparency. In this report, the researcher suspects that the size of the board of Commissioners, the concentration of ownership, and the Risk Management Committee will all impact Corporate Risk Management disclosure. Thus, the agency theory states a conflict between managers' decisions to maximize their satisfaction, which, in fact, does not prosper shareholders. Thus, it assumes that individuals who have positions in a company do not necessarily have goals following the owner's mandate in the following tract, namely increasing the company's wealth. However, disclosure of Enterprise Risk Management can be proven management can prevent disclosure of Enterprise Risk Management such as independent commissioners, with the high number of independent commissioners, the concentration of ownership and management committees, which risk is expected to inhibit and limit managers' intentions to commit fraud.

\section{Analysis of the Literature and Formulation of Hypotheses}

\subsection{Agency Theory}

So far, agency theory is a theory commonly used in corporate business practice. Agency theory states a working relationship between the party giving the authority (principal) and the party receiving the authority (agent) in the form of a cooperation contract created because of conflicting interests. What is meant by a principal in agency theory is the owner of the company or shareholders. What is meant by the agent is management, who is obliged to manage the owner's assets. There is a difference in interests between the principal and agent, which creates a conflict of information asymmetry. This conflict arises because of the desire of managers to maximize their level of satisfaction. And on the other hand, shareholders want to maximize their profits; conflict arises if managers' decisions to maximize their satisfaction are not in the welfare of shareholders. Jensen and Meckling (1976) state that agency conflict arises in various ways into four motivations: Moral Hazard is dishonest behavior at the expense of other parties' interests; for example, management chooses the most suitable investment for itself and not the most profitable company. Earning Retention, where management tends to maintain a stable company income level, while shareholders prefer a higher cash distribution through several positive internal investment opportunities. Risk Aversion is where management tends to experience a safe position for themselves in making investment decisions. In this case, management will make very safe investment decisions and within the manager's ability. Usually, they tend to avoid investment decisions because they are considered to increase their company's risk even though this may not be the best choice for the company. And finally, Time Horizon, which is where management usually only pays attention to the company's cash flow statement in line with the predetermined assignment time. Thus, it can lead to bias in decision making, namely in favor of short-term projects with high accounting returns and less or not in favor of long-term projects with much greater returns on net present value. An auditor can minimize the conflict between the shareholder (principal) and the company management (agent) in several ways. Namely, the manager must run the company according to the interests of the shareholders, and the manager must make decisions based on the interests of the shareholders. Further, in running the company, the manager can also be monitored by the stakeholders. Shareholders.

\subsection{Signaling Theory}

Signaling Theory or signal theory discusses the company's urge to provide information to external parties. The signal theory 
emerged because of the problem of information asymmetry between management and external parties. Therefore, to reduce the information asymmetry that will occur, the company must disclose the information it has, financial and non-financial information. The use of signaling theory in risk disclosure in corporate management is generally beneficial for companies to create good quality companies in the market. Although no regulation mandates Enterprise Risk Management implementation specifically, companies can still implement and disclose Enterprise Risk Management in their commitment to implementing corporate governance practices.

\subsection{Board Of Commissioners Size and Enterprise Risk Management Disclosure}

The board of commissioners in risk management can prevent any indication of confidential information by exercising adequate supervision. When it comes to carrying out its tasks, efficient supervision means adhering to corporate governance standards. Thus, it can reduce asymmetric information that can improve company risk information quality if associated with agency theory problems. The research results of Manurung and Kusumah (2016) and Sulistyaningsih and Gunawan (2018) demonstrate that the size of the board of commissioners has an effect on the disclosure of Enterprise Risk Management A bigger board would be more proactive in supervising and forming committees with the necessary expertise, such as a risk management committee. In comparison to the findings of the study by Dzakawali et al. (2017), the scale of the board of commissioners has little impact on the disclosure of corporate risk management. An organization must be able to ensure that the risk management strategy in place is successful. In overseeing the risk management system, the board of commissioners' competence and size are related to the effectiveness of the commissioners' supervision. The board of commissioners has the power to supervise risk control and ensure that the organization has an efficient risk management policy. According to the association between organization theory and previous studies, the size of the Board of Commissioners has a favorable impact on Business Risk Management Transparency

$\mathrm{H}_{1}$ : Size of board of commissioners has a positive effect on ERM disclosure.

\subsection{Ownership Concentration and Enterprise Risk Management Disclosure}

Shareholders would have controlling powers over a corporation with a concentrated ownership arrangement, reducing the dispute between the principal and agent. Agencies issues and costs can be minimized or removed in businesses with a concentrated ownership structure. The study results by Asriani (2017) show that Ownership Concentration has a positive effect on Enterprise Risk Management Disclosure. Because the greater the level of ownership concentration in the company, the stronger the demands to identify the risks and risk disclosure to the public that the company may face. Meanwhile, the research results by Raymond and Meiranto (2016) and Irawan and Pangestuti (2015) show that ownership concentration does not affect Enterprise Risk Management disclosure. The majority shareholder usually holds greater control of the company to put pressure on the management to disclose broader risk information in controlling the company to prevent the possible impact of the losses they will face. Based on the relationship between agency theory and ownership concentration and supported by previous research, ownership concentration has a positive effect on Enterprise Risk Management Disclosure.

\section{$\mathrm{H}_{2}$ : Ownership concentration has a positive effect on ERM Disclosure.}

\subsection{Risk Management Committee and Enterprise Risk Management Disclosure}

According to signal theory, an organization can establish a Risk Management Committee to demonstrate its commitment to good corporate governance practices and to improve the company's credibility and valuation. As a result, once the organization establishes a Risk Management Committee, Enterprise Risk Management's transparency would become much more detailed. Research by Sari et al. (2019) notes that the Risk Management Committee variable is the most dominant variable and has a major positive impact on Business Risk Management transparency A risk management committee will increase the level of risk evaluation and supervision while also encouraging businesses to report the risks (Sari et al., 2019). Companies that have a risk management committee will rely more on addressing the different threats they face, allowing for greater risk management disclosures. The risk management committee is an agency of the board of commissioners that assists in the oversight and control of the company's risk management implementation. The risk assessment committee supports the board of commissioners by shaping risk disclosure policies. According to previous studies and based on the association between organization philosophy and the Risk Management Committee, the Risk Management Committee has a positive impact on Enterprise Risk Management Disclosure.

$\mathrm{H}_{3}$ : Risk Management Committee has a positive effect on ERM Disclosure.

\subsection{Company Size and Enterprise Risk Management Disclosure}

According to agency theory, big companies have higher agency costs than small firms. As a result, big corporations may share 
more details in order to reduce organization expenses. According to the study's findings, organization size has a favorable impact on Enterprise Risk Management transparency (Yunifa \& Juliarto, 2017). The size of the firm has a favorable association with risk disclosure, as the larger the company, the more people can invest in it. As a result, greater risk transparency has occurred, as well as a form of corporate accountability to investors. According to the study's conclusions, the size of a business has no impact on the disclosure of Corporate Risk Management (Asriani, 2017). Larger corporations traditionally follow stronger corporate governance policies than smaller companies, and the larger the business, the greater the amount of risk posed, such as revenue, organizational, reputational, legal, and intelligence risks. As a result, major firms will face increased pressure to report higher-level threats of management corporations in order to achieve market disclosure and identify different risks that could be encountered. Based on the association between organization theory and business size, and backed by prior analysis, Company Size has a beneficial impact on Enterprise Risk Management Disclosure.

\section{$\mathrm{H}_{4}$ : Company Size has a positive effect on ERM Disclosure.}

\subsection{Leverage and Enterprise Risk Management Disclosure}

According to agency theory, an organization with a higher leverage level would report more detail so the agency expenses associated with such a capital structure are higher. Creditors can compel a firm to share more detail if it has a greater risk of leverage in its capital structure. concluded that leverage has a beneficial impact on Enterprise Risk Management transparency The greater the company's debt ratio, the greater the degree of company management liability disclosure, and the greater a company's debt level, the greater the need for reporting reports from creditors (Marhaeni \& Yanto, 2015). The study results (Khumairoh \& Agustina, 2017) show that Leverage does not affect Enterprise Risk Management disclosure. Companies with high debt levels must fully report uncertainties in their financial statements to reflect the commitment of their creditors. Based on the association between organization theory and leverage, as well as prior studies demonstrating that leverage has a beneficial impact on Enterprise Risk Management Disclosure.

\section{$\mathrm{H}_{5}$ : Leverage has a positive effect on ERM Disclosure.}

\section{Research method}

The information used comes from financial firm statements. The authors were involved in insurance firms listed on the Indonesia Stock Exchange between 2015 and 2019. (IDX). Since it is used to analyze the survey results if all population samples are used as test data, the purposive sampling approach is considered adequate in this study. During the five-year survey period, ten insurance firms met the requirements and served as a research sample.

Table 1

Operational Variables

\begin{tabular}{|c|c|c|c|}
\hline Variable & Operational Variables & Proxy & $\begin{array}{c}\text { Measure } \\
\text { Scale }\end{array}$ \\
\hline $\begin{array}{l}\text { Disclosure } \\
\text { Enterprise risk } \\
\text { management }\end{array}$ & $\begin{array}{l}\text { Enterprise risk management is a summary of how } \\
\text { organizational risk management is applied. The will the } \\
\text { number of products revealed, the more likely it is that } \\
\text { appropriate risk control can be implemented. }\end{array}$ & $I P E R M=\frac{\text { The total value of the items disclosed }}{\text { value that should have been disclosed }}$ & Ratio \\
\hline $\begin{array}{l}\text { Board of } \\
\text { Commissioners } \\
\text { Size }\end{array}$ & $\begin{array}{l}\text { Part of the company organ in charge of general and } \\
\text { specific oversight, as well as consulting the board of } \\
\text { directors, in compliance with the terms of association. }\end{array}$ & $\begin{array}{c}\text { UDK }=\text { Number of Members of the Board of } \\
\text { Commissioners }\end{array}$ & Ratio \\
\hline $\begin{array}{l}\text { Ownership } \\
\text { Concentration }\end{array}$ & $\begin{array}{l}\text { Ownership concentration describes how and who has } \\
\text { control over the company's ownership and who has } \\
\text { control over the business activities of a company. }\end{array}$ & $O C=\frac{\text { The largest number of shareholdings }}{\text { Total company shares }}$ & Ratio \\
\hline $\begin{array}{l}\text { Risk } \\
\text { Management } \\
\text { Committee }\end{array}$ & $\begin{array}{l}\text { An organ of the board of commissioners that helps } \\
\text { supervise and monitor the implementation of risk } \\
\text { management in the company }\end{array}$ & $\begin{array}{l}\text { Using a dummy variable, the value is } 1 \text { if expressing } \\
\text { and the value is zero if it is not disclosed }\end{array}$ & Ratio \\
\hline Company Size & $\begin{array}{l}\text { A value that represents the scale or size of an organization } \\
\text { is known as company size. }\end{array}$ & Company Size $=$ Ln Total Asset & Ratio \\
\hline Leverage & $\begin{array}{l}\text { a tool to measure how much the company depends on } \\
\text { creditors in financing the company's assets }\end{array}$ & leverage $=\frac{\text { total debt }}{\text { total asset }}$ & Ratio \\
\hline
\end{tabular}

Source: Secondary data processed. 2020

The data management approach will be applied after the variables and their quantities have been defined. The reporting methodology approach is considered suitable for secondary data analysis. Following the compilation of data for this report, a descriptive interpretation evaluation will be conducted. The GLS Regression test panel data were used in hypothesis testing to determine if the data structure has a significant image to determine whether or not there is a data linkage. Panel regression analysis data are secondary data that were chosen based on the results of sample test comparisons (Chow, Hausman and 
Lagrange Multiplier). The Common Effect Model, the Fixed Effect Model, or the Random Effect Model are used to allocate Prob F effects later. In addition, multicollinearity and heteroscedasticity checks will be performed. It is carried out if the prediction form used is Ordinary Least Squares (CEM and FEM). If, on the other hand, the Random Effect model is used, there is no need for further testing since the GLS Regression has already been processed in the previous testing step. As the performance of the chosen model, the panel data regression equation can be used as data to analyze the regression results.

\section{Results}

The panel data regression methods used in this research was based on the three models, the pair test results on the three models can be seen in the Table 2 below:

Table 2

Model Estimation Test Results

\begin{tabular}{|c|c|c|c|c|}
\hline \multirow[t]{2}{*}{ Effect Test } & \multirow[t]{2}{*}{ Prob $>$ F } & \multicolumn{3}{|c|}{ Best Model } \\
\hline & & Determining test & $($ Prob $>$ F $) /($ Prob $>$ Chibar2 $) /($ Prob $>$ Chi2 $)$ & Description \\
\hline Ordinary Least Square (OLS) & 0.0000 & Chow test (OLS vs FE) & 0.0018 & Fixed Effect \\
\hline Fixed Effect (FE) & 0.0000 & Hausman test (FE vs RE) & 0.0177 & Fixed Effect \\
\hline Random Effect (RE) & 0.0000 & LM test(OLS vs RE) & 0.0460 & Random Effect \\
\hline
\end{tabular}

The fixed effect model (FEM) model of panel data regression is used further in estimating the effect of the Board of Commissioners' scale, based on the results of the study of three panel data regression models. Corporate Risk Management Transparency is affected by ownership concentration, the Risk Management Team, the size of the company, and leverage in the ten insurance firms surveyed between 2015 and 2019. Table 3 below illustrates this:

Table 3

Blue Test Result

\begin{tabular}{lcrr}
\hline & UDK & OC & RMC \\
\hline UDK & 1.000000 & & \\
OC & -0.179707 & 1.000000 & \\
RMC & -0.073793 & 0.238856 & 1.000000 \\
SIZE & -0.621752 & -0.322960 & -0.231634 \\
DAR & 0.086059 & -0.149822 & -0.022388 \\
\hline Breusch-Pagan LM & 0.0753 & & 0.099072 \\
F-statistic & 7,616950 & & 1.000000 \\
Prob(F-statistic) & 0.000001 & & \\
\end{tabular}

Table 3 demonstrates that there are independent variables with values greater than 0.8 . As a result, the regression model has no multicollinearity. The Prob meaning can be seen in the table above. Since the Breusch-Pagan LM is greater than 0.05, it can be inferred that $\mathrm{HO}$ is accepted, implying that the panel data regression model does not exist.

Table 4

\section{Research's Hypotheses Test Results}

\begin{tabular}{|c|c|c|c|c|c|}
\hline Hyp. & Hypothesis Statement & Coef. Value & $\mathbf{P}>|\mathbf{z}|$ & Sig & Model \\
\hline 1. & $\begin{array}{l}\text { Are board of Commissioners Size have positive affected to } \\
\text { ERM Disclosure. }\end{array}$ & 0.7529 & Hypothesis denied & - & $\begin{array}{l}\text { IPERM }=-1.009313- \\
0.002586 \mathrm{UDK}+\end{array}$ \\
\hline 2. & $\begin{array}{l}\text { Are Ownership Concentration have positive affected to ERM } \\
\text { Disclosure. }\end{array}$ & 0.4723 & Hypothesis denied & - & $\begin{array}{c}0.026977 \mathbf{~ O C}+ \\
0.044313 \mathbf{R M C}+\end{array}$ \\
\hline 3. & $\begin{array}{l}\text { Are Risk Management Committee have positive affected to } \\
\text { ERM Disclosure }\end{array}$ & 0.1505 & Hypothesis denied & - & $\begin{array}{c}0.052430 \text { SIZE - } \\
0.007831 \text { DAR + eit }\end{array}$ \\
\hline 4. & Are Company Size have positive affected to ERM Disclosure & 0.0156 & Hypothesis accepted & $\sqrt{ }$ & \\
\hline 5. & Are Leverage have positive affected to ERM Disclosure & 0.1852 & Hypothesis denied & - & \\
\hline
\end{tabular}

\section{Discussion}

\subsection{Board Of Commissioners Size Not Increasing Enterprise Risk Management Disclosure}

Checking the first theory indicates that the composition of the Board of Commissioners has little impact on Business Risk Management Transparency. As a consequence, there are already contradictions in the findings of the suggested hypothesis's responses. The board of commissioners, who have the role and duty of supervising management actions in carrying out the 
company's agenda, is the manager of a company. However, the composition of the board of commissioners has little bearing on the consistency of management's supervisory role in an insurance firm. However, the regulation system is determined by the company's principles, norms, and convictions. Since there are many views and opinions of board members that Commissioners must unify, a large board of commissioners can delay decision-making and increase the likelihood of internal conflict. Thus, causes supervision in implementing risk management disclosures in insurance companies to be ineffective. This study's results are not in line with the research by Manurung and Kusumah (2016) and Sulistyaningsih and Gunawan (2018), where the study findings indicate that the composition of the board of commissioners influences the disclosure of Enterprise Risk Management However, the findings of this report are consistent with previous studies (Dzakawali et al., 2017), that specifies that the size of the board of commissioners has little impact on Business Risk Management disclosure.

\subsection{Ownership Concentration Not Increasing Enterprise Risk Management Disclosure}

The second hypothesis testing shows that Ownership Concentration does not affect Enterprise Risk Management Disclosure. Thus, it shows that there are still inconsistencies in the results of the answers to the proposed hypothesis. Ownership concentration describes how and who has control over the company's ownership and who has control over business activities in the company. However, the more concentrated ownership in the company causes the majority shareholder to control the company and increasingly influence decision-making. The increasing concentration of ownership in the company will reduce the disclosure of Enterprise Risk Management. Also, the majority shareholder will have the view that it is no longer in his interest regarding the protection of minority shareholders and risk management mechanisms because there is a possibility that shareholders are not so concerned with disclosing the company's Enterprise Risk Management due to other interests that they want to make to gain profits from the company. This study's results are not following research (Asriani, 2017), showing that Ownership Concentration has a positive effect on Enterprise Risk Management Disclosure. However, this study's results follow the results of research (Raymond \& Meiranto, 2016), which show that ownership concentration does not affect the disclosure of Enterprise Risk Management.

\subsection{Risk Management Committee Not Increasing Enterprise Risk Management Disclosure}

Testing the third hypothesis shows that the Risk Management Committee does not affect Enterprise Risk Management Disclosure. This shows that there are still inconsistencies in the results of the answers to the proposed hypothesis. The Risk Management Committee is an organ of the board of commissioners that helps supervise and monitor risk management implementation in the company. Supervision and monitoring in the implementation of risk management in the company's company are not adequate because risk management's responsibility rests with the board of commissioners and directors. The existence of the Risk Management Committee has led to an increase in disclosure of company management risks, resulting in too much company information being published so that it becomes a consideration for investors to invest in the company. The disclosure of Enterprise Risk Management would be reduced if the company's Risk Management Committee is expanded. Insurance firms' premiums would escalate as a result of the presence of a Risk Control Committee. This study's results are not following the results of the study (Sari et al., 2019), which states that the Risk Management Committee variable is the most dominant and has a significant positive effect on Enterprise Risk Management disclosure.

\subsection{Company Size Increasing Enterprise Risk Management Disclosure}

The Fourth hypothesis shows that the size of the company affects the disclosure of enterprise risk management. This shows that there is consistency in the results of the answers to the proposed hypothesis. Company size is the company's level in which there is labor capacity, production capacity and capital capacity. Companies with large sizes generally tend to adopt better corporate governance practices than small companies because the more significant the company, the higher the risk faced, such as financial, operational, reputational, regulatory, and information risks. As a result, a company with large size will have a solid demand to disclose the risks higher to management corporations aimed at public transparency and identifying various risks to determine how the company's condition is from the risk side that the company will face. This study's results are not following the research results (Asriani, 2017), which show that company size does not affect Enterprise Risk Management's disclosure. However, the results of this study are following the results of research (Yunifa \& Juliarto, 2017), which concluded that company size affects the disclosure of Enterprise Risk Management

\subsection{Leverage Not Increasing Enterprise Risk Management Disclosure}

Hypothesis testing shows that Leverage does not affect Enterprise Risk Disclosure Management. This shows that there are still inconsistencies in the results of the answers to the proposed hypothesis. Leverage is a ratio that shows the percentage of the provision of funds by shareholders to lenders or a ratio that assesses the amount of debt the company uses. The higher the level of corporate Leverage, the greater the company's level of dependence on external parties (creditors), so that the company is 
more at risk of difficulties in paying its obligations and interest. Companies with high debt tend to be careful in carrying out their activities, including disclosing risk management. To carry out extensive risk management disclosures, of course, requires a lot of funds. Therefore, it is suspected that companies whose sources of funds come from third parties will prefer to use these funds for matters that they prioritize so that there is no impact on risk management disclosure. In this condition, the company will tend to disclose less risk management because the high Leverage level causes investors to hesitate to invest in the company. This study's results are not following the research by Marhaeni and Yanto (2015) who concluded that Leverage has a positive effect on the disclosure of Enterprise Risk Management. However, this study's results follow the results of research (Khumairoh \& Agustina, 2017), showing that Leverage does not affect the disclosure of Enterprise Risk Management.

\section{Conclusions and Research's Limitations}

The results of the analysis and discussion of the results of the first variable test show that the board of commissioners' size, the concentration of ownership, risk management committee, company size, and leverage partially do not affect the disclosure of enterprise risk management. A positive influence between company size and Enterprise Risk Management Disclosure means that companies with large-sized types will have intense demands to disclose higher risks management corporate aimed at public transparency and identify various risks that risk may face. This is following the requirements of the criteria for insurance needs. The study's drawbacks include the fact that it only looked at insurance firms listed on the Indonesia Stock Exchange (IDX) from 2015 to 2019. In this study, the lack of references from previous research makes this research have many shortcomings. Based on the results of the discussion and conclusions above, suggestions are given for the company. Namely, this research can provide an overview of that disclosure of Enterprise Risk. Management needs to be disclosed in financial reports to provide information about the company's risks in every activity for stakeholders. We can find out the condition risk of the company in terms of risks that the company will face. Furthermore, for investors and potential investors, this research is expected to provide investors and potential investors with information as material for consideration in making investment and credit decisions by looking at how the company implements risk management to maximize the profits obtained. For the next researcher, further research should expand the sector to be studied to get a larger sample of companies because the more companies studied are expected to provide better results.

\section{References}

Alahmari, A. (2020). Cybersecurity Risk Management In Small And Medium-Sized Enterprises: A Systematic Review Of Recent Evidence. 2020 International Conference On Cyber Situational Awareness, Data Analytics And Assessment, Cyber Sa 2020. Https://Doi.Org/10.1109/Cybersa49311.2020.9139638

Asriani, N. (2017). Faktor-Faktor Yang Memengaruhi Pengungkapan Enterprise Risk Management (Erm) (Studi Empiris Pada Perusahaan Perbankan Yang Terdaftar Di Bursa Efek Indonesia Pada Tahun 2013-2015) (University Of Muhammadiyah Yogyakarta; Vol. 0). Retrieved From Http://Repository.Umy.Ac.Id/Handle/123456789/7982?Show=Full

Ayyagari, M., Beck, T., \& Demirguc-Kunt, A. (2007). Small And Medium Enterprises Across The Globe. Small Business Economics, 29(4), 415-434. Https://Doi.Org/10.1007/S11187-006-9002-5

Bromiley, P., Mcshane, M., Nair, A., \& Rustambekov, E. (2015). Enterprise Risk Management: Review, Critique, And Research Directions. Long Range Planning, 48(4), 265-276. Https://Doi.Org/10.1016/J.Lrp.2014.07.005

Burgstaller, W. (2013). How Do Family Ownership And Founder Management Affect Capital Structure Decisions And Adjustment Of Smes. The Journal Of Risk Finance, 16(1), 73-101.

Cepel, M., Stasiukynas, A., Kotaskova, A., \& Dvorsky, J. (2018). Business Environment Quality Index In The Sme Segment. Journal Of Competitiveness, 10(2), 21-40. Https://Doi.Org/10.7441/Joc.2018.02.02

Dvorsky, J. (2020). Business Risk Management In The Context Of Small And Medium-Sized Enterprises. Economic ResearchEkonomska Istrazivanja. Https://Doi.Org/10.1080/1331677x.2020.1844588

Dzakawali, M. G., Nazar, M. R., \& Yudowati, S. P. (2017). Dewan, Pengaruh Ukuran Komisaris, Ukuran Perusahaan Dan Konsentrasi Kepemilikan Terhadap Yang, Pengungkapan Enterprise Risk Management (Studi Pada Sektor Perbankan Of, Listing Di Bursa Efek Indonesia (Bei) Tahun 2013-2015). Eproceedings Management, 4(3).

Irawan, P., \& Pangestuti, I. R. D. (2015). Pengaruh Struktur Kepemilikan, Corporate Governance ,Dan Underwriter Reputation Terhadap Ipo Underpricing ( Studi Empiris Pada Perusahaan Yang Ipo Di Bursa Efek Indonesia Tahun 2006-2014 ). Diponegoro Journal Of Manajement, 4(4), 1-12.

Jensen, C., \& Meckling, H. (1976). Theory Of The Firm : Managerial Behavior , Agency Costs And Ownership Structure I . Introduction And Summary In This Paper Wc Draw On Recent Progress In The Theory Of ( 1 ) Property Rights , Firm . In Addition To Tying Together Elements Of The Theory Of E. 3, 305-360.

Khumairoh, N. A., \& Agustina, L. (2017). The Roles Of The Board Of Commissioner In Moderating Factors Affeting The Disclosure Of Enterprise Risk Management. Accounting Analysis Journal, 6(3), $445-457$. Https://Doi.Org/10.15294/Aaj.V6i3.18908

Manurung, D. T. H., \& Kusumah, R. W. R. (2016). Telaah Enterprise Risk Management Melalui Corporate Governance Dan Konsentrasi Kepemilikan. Jurnal Akuntansi Multiparadigma, (204), 335-348. 
Https://Doi.Org/10.18202/Jamal.2016.12.7025

Marhaeni, T., \& Yanto, H. (2015). Determinan Pengungkapan Enterprise Risk Management (Erm) Pada Perusahaan Manufaktur. 4(4), 1-22. Retrieved From Http://Journal.Unnes.Ac.Id/Sju/Index.Php/Aaj

Raymond, H. A., \& Meiranto, W. (2016). Analisis Pengaruh Good Corporate Governance Dan Konsentrasi Kepemilikan Terhadap Pengungkapan Enterprise Risk Management (Studi Empiris Pada Perusahaan Manufaktur Yang Terdaftar Di Bursa Efek Indonesia Tahun 2012-2015) (Diponegoro University; Vol. 0). Retrieved From Http://Eprints.Undip.Ac.Id/50608/

Sari, D. R., Cahyono, D., \& Maharani, A. (2019). Pengaruh Ukuran Dewan Komisaris Dan Risk Management Committee Terhadap Pengungkapan Enterprise Risk Management. Jurnal Akuntansi Profesi, 10(2), $139-149$. Https://Doi.Org/Http://Dx.Doi.Org/10.23887/Jap.V10i2.23070

Sulistyaningsih, S., \& Gunawan, B. (2018). Analisis Faktor-Faktor Yang Memengaruhi Risk Management Disclosure (Studi Empiris Pada Perusahaan Manufaktur Yang Terdaftar Di Bursa Efek Indonesia Tahun 2012-2014). Riset Akuntansi Dan Keuangan Indonesia, 1(1), 1-11. Https://Doi.Org/10.23917/Reaksi.V1i1.1973

Yunifa, L., \& Juliarto, A. (2017). Analisis Pengaruh Karakteristik Perusahaan Terhadap Tingkat Pengungkapan Risiko Pada Perusahaan Manufaktur. Diponegoro Journal Of Accounting, 6(3), 538-549.

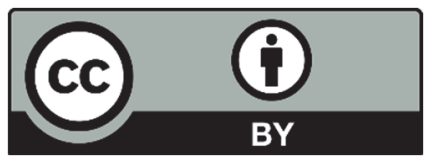

(C) 2021 by the authors; licensee Growing Science, Canada. This is an open access article distributed under the terms and conditions of the Creative Commons Attribution (CC-BY) license (http://creativecommons.org/licenses/by/4.0/). 